\title{
En upåagtet dimension i Grundtvigs tanker om "Anskuelsen"
}

\author{
Af K. E. Bugge
}

I årene efter angrebet på $\mathrm{H}$. N. Clausen og den deraf følgende injurieproces har Grundtvig efterhånden følt et behov for at kæmpe sig ud af den marginaliserede position, som disse begivenheder havde medført. I 1831 formulerede Grundtvig derfor et idégrundlag, ud fra hvilket han opfordrer troende og ikke-troende til at samarbejde om de presserende kulturopgaver, bl.a. en reform af skolevæsenet. Dette nyformulerede idégrundlag betegner Grundtvig i indledningen til sit store værk Nordens Mythologi (1832) som "Anskuelsen". I sin redegørelse for "Anskuelsens" indhold går Grundtvig ud fra som givet, at troende og ikke-troende kan være enige om de elementer af et livssyn, der $\mathrm{i}$ teologisk sammenhæng betegnes med begreberne skabelse og syndefald. Om frelsen, derimod, er efter hans opfattelse enighed umulig. Nærværende artikel rejser spørgsmålet om, hvorfor Grundtvig med så stor sikkerhed kunne gå ud fra, at netop disse forudsætninger var til stede hos hans læsere. Svaret er sandsynligvis at finde i datidens lærebøger i kristendomskundskab inden for almueskolen og den lærde skole.

I indledningen til Nordens Mythologi (1832) lancerer Grundtvig, som bekendt, en sondring mellem tro og anskuelse. ${ }^{1}$ Med ordet Anskuelse betegner han en livsforståelse, hvis grundelementer findes inden for de områder, der i traditionel teologisk sprogbrug dækkes af begreberne skabelse og syndefald. Hvad enten man er "Christen eller Hedning, Tyrk eller Jøde", hedder det, må man være overbevist om, at mennesket er skabt i Guds billede, samt enige om, at mennesket på et vist tidspunkt kom i misforhold til sin egentlige bestemmelse. De "hedninger", Grundtvig her tænker på, benævner han "Naturalister". Med dette udtryk mener han mennesker, der ikke er bundet af et snævert biologisk eller mekanistisk livssyn, men som har sans for, at "Aand" er en væsentlig bestemmelse ved at være menneske. "Naturalister" er med andre ord alle de ikke-troende i fortid og nutid, der har haft og har "Glimt af Aand og Gnist af Sandhedskiærlighed". Grundtvig er klar over, at naturalisterne muligvis vil være forbeholdne over for udtrykket "Syndefald". Han gør sig derfor umage med at finde mindre belastede udtryk, som for eksempel "et stort Uheld" eller "Vilde-Rede". Det vigtigste er enighed om selve sagen.

Så vidt anskuelsen og den vidtgående enighed, som på det grundlag kan etableres. Uenighed opstår derimod, når man taler om tro, det vil sige når man skal bestemme, hvorledes der skal rådes bod på den ved syndefaldet eller "uheldet" forvoldte skade. Den kristne tror, at dette kan ske ved en forening mellem det $\mathrm{i}$ dåben genfødte menneske 
og frelseren Jesus Kristus. Naturalisten, derimod, vil hævde, at redningen kommer i stand på den måde, at mennesket optager Kristus i sig som et guddommeligt forbillede. På dette punkt, vedrørende menneskets redning/frelse, er modsætningen mellem de to livssyn uovervindelig. Her er al mæglen umulig. Her gælder et enten-eller. Når dette bliver klart, siger Grundtvig, da står vi "som Chaldæer og Copernicaner i Aandens Verden".

\section{Konsekvenser og forudscetninger}

Hvad konsekvenserne angår, fastslår Grundtvig straks, at når sondringen mellem tro og anskuelse er gennemført, da kan kristne og naturalister "holde Skole sammen". Uenighed om vejen til menneskelivets endelige mål må man indtil videre lade ligge. Kun tiden kan afgøre, hvem der har ret. I mellemtiden må man på grundlag af de elementer i menneskesynet, man er enige om, det vil sige på grundlag af "Anskuelsen", kunne samarbejde om løsningen af de nødvendige samfundsopgaver.

Det er vigtigt at fastslå, at den fælles basis, Grundtvig her søger at etablere for et samarbejde med anderledes tænkende, ikke alene er at finde i skabelsestanken, således som det undertiden hævdes. Anskuelsen omfatter både en skabelsestanke, altså tanken om en oprindelig, Gud-skabt orden, og tanken om en derpå følgende ødelæggelse. I det øjeblik det bliver klart, at "Anskuelsen" ikke alene omfatter skabelsestanken, men også tanken om et "Vilde-Rede" eller syndefald, hvordan man end udtrykker det, da melder sig spørgsmålet om, hvorfor Grundtvig formulerede sig på netop denne måde. Hvorfor argumenterer han for et fælles todelt idégrundlag for straks derefter at adskille dette skarpt fra en tredje overbevisning? Sigter han til nogle bestemte tankegange, som han forudsætter bekendt? Med andre ord: Hvad er tilknytningspunktet mellem ham og de læsere, han henvender sig til? For nylig har Sune Auken understreget, at i Nordens Mythologi fra 1832 er "forholdet mellem den talende stemme, værket selv og læseren (...) en af bogens vigtigste strukturer" (Auken 2005, 520 f.). Grundtvig må derfor også med hensyn til sine tanker om "Anskuelsen" have haft sin læser og dennes forudsætninger for øje. Han må have været overbevist om, at læserne - i hvert fald et stykke hen ad vejen ville nikke genkendende til det, han sagde. Hvilke teologiske forudsætninger har Grundtvig da regnet med, at han havde fælles med dem, han henvendte sig til?

$\mathrm{Da}$ argumentationen inddrager centrale teologiske begreber som skabelse, syndefald og til dels også frelse, vil en passende betegnelse for det spørgsmål, der her rejses, være, at man efterlyser Grundtvigs normalteologiske forudsætninger. I sin disputats fra 1949 efterlyste Henning Høirup Grundtvigs "normalfilosofiske forudsætninger", det 
vil sige de antagelser af almenfilosofisk art, som Grundtvig delte med sine samtidige. I nærværende sammenhæng kan man rejse det beslægtede spørgsmål om, hvilke teologiske antagelser der som noget helt selvfølgeligt indgik i de refleksioner, som datidens mennesker gjorde sig om menneskelivets vilkår og mening. Svaret finder vi i datidens lærebøger i kristendomskundskab eller i "Den evangelisk-christelige Religion", som man den gang udtrykte sig. Det er derfor nærliggende at se lidt nærmere på de lærebøger, som vi ved, at Grundtvig har kendt. Det drejer sig om Johan Grundtvigs Catechismi Forklaring efter Saliggiørelsens Orden fra 1779 og N. E. Balles Larebog i den evangeliskchristelige Religion fra 1791. Den førstnævnte bog repræsenterer den såkaldte "Forklarings-genre" inden for luthersk kateketisk tradition. Sammen med Luthers katekismus udgjorde sådanne udførligere "Forklaringer" grundlaget for datidens kristendomsundervisning i kirke og skole. I forhold til denne tradition betegner Balles lærebog et nybrud. Ifølge en kommissionsbetænkning fra 1786 opfordredes biskoppen til at udarbejde "en passende kort og kiærnefuld Lærebog". Udtrykket "passende kort" antyder, at man havde indset, at de meget omfattende katekismeforklaringer var uegnede for børn. Balle forlader bevidst Forklarings-genren både med hensyn til omfang og struktur. Mens Johan Grundtvigs bog er på 240 sider, er Balles "passende kort" - på kun 104 sider! Endvidere er hans lærebog ikke som forklaringerne opbygget efter katekismens fem hovedstykker, men er en systematisk anlagt lille teologi for børn. Bogen, der som nævnt udkom i 1791, fik i kraft af sin autorisation en betydelig udbredelse. ${ }^{2}$

Johan Grundtvigs og Balles lærebøger må på denne baggrund tiltrække sig størst interesse. Ikke alene har Grundtvig kendt disse bøger, men de illustrerer endvidere nogle helt grundlæggende religionspædagogiske brydninger $\mathrm{i}$ tiden omkring århundredskiftet. Ud over disse to bøger inddrages - for at tilføje et videre perspektiv tillige enkelte andre af de lærebøger, der udkom i tiden mellem 1700tallets sidste årtier og 1831/32, det år, hvor Grundtvig skrev sin Nordens Mythologi (1832). Vi begynder med lærebøger for børn, og retter dernæst søgelyset mod lærebøger for de lidt ældre årgange, der var disciple i datidens latinskoler.

\section{Larebøger for børn}

\section{Om skabelse}

Grundtvig fik faderens katekismeforklaring foræret i 1791, og hans første kommentar dertil er fra 1798. Desuden har han kendt og kommenteret sin onkel, biskop N. E. Balles lærebog. ${ }^{3}$ I Johan Grundtvigs katekismeforklaring (Grundtvig 1779) hedder det i første "Hovedstykke" om skabelsen blandt andet: 
Spm: Hvorledes kan man af Verdens Skabelse og Vedligeholdelse vide, at der er en Gud til?

Svar: Verden kan umuelig have skabt sig selv eller vedligeholde sig selv, ligesom et Huus har ikke bygt eller kan vedligeholde sig selv; altsaa maae Verden have en ældre og høyere Aarsag, som har skabt og vedligeholder den. (§ 4)

Argumentationen ligger tæt op ad de formuleringer, som svogeren $\mathrm{N}$.

E. Balle anvendte i den af ham forfattede lærebog:

$\S$ 3.a) Hvo, som vil bruge sin Fornuft, erkiender letteligen, at Verden ikke kan være blevet til af sig selv, ligesaalidet som et Huus eller en Bye, kan bygge sig selv; thi der er ikke nogen Ting til, som jo <ej> haver havt sin Aarsag, hvoraf den er kommet.

Balles afvigelse fra Johan Grundtvigs lærebog består først og fremmest i den udtrykkelige henvisning til menneskets fornuft. Ser man på endnu en lærebog fra perioden, P. O. Boisens fra 1818, møder man tilsvarende tanker. Her anføres ligesom i de to førnævnte lærebøger eksemplet med et hus, der umuligt kunne have bygget sig selv. Samme argumentation, men med variation i eksemplerne, genfindes $\mathrm{i}$ andre af tidens lærebøger, for eksempel hos Christian Bastholm og Hans Gram Bechmann. I Bastholms religionsbog for ungdommen (Bastholm 1785) hedder det i første kapitel stk. 2 (s. 19):

Alle disse Ting, som vi see, kunne ikke være til af sig selv, eller være
saaledes indrettede af sig selv, ligesaa lidet som et Uhr, et Huus, en
Mølle er til af sig selv, og er indrettet af sig selv, altsaa ere frembragte
af en anden, som er høiere og ypperligere end alle disse Ting, og ham
kalde vi Gud.

I Bechmanns lærebog fra 1813 er eksemplerne forøget med "et Græsstraae eller Sandskorn" (s. 9 og 23). At synspunktet gentages gang på gang og med begrænset variation i eksemplerne, er et vidnesbyrd om dets udbredelse i samtiden.

\section{Om syndefald}

I Johan Grundtvigs Catechismi Forklaring begrundes menneskelig ondskab ud fra arvesynden. I spm. 140 spørges, om Adams og Evas fald også strakte sig til os og alle vore børn. Derpå svares:

Ach! Ja, desverre; thi al Menneskenes Slegt er af eet Blod, og da Adam og Eva vare blevne Syndere, saa kunde de ikke avle bedre Børn, end de selv vare, derfor ere vi alle Syndere og Vredens Børn af Naturen. [Deraf følger, at arvesynden kan defineres som] en medfødt Fordervelse i vor Natur, at vi mangler alt aandeligt Godt, og haver Afskye dertil, og derimod ere tilbøyelige til alt Ondt (s. 45).

Synspunktet stemmer godt overens med Bastholms lærebog, hvis første oplag kom i 1785, og hvor det hedder, at "Alle Adams 
Efterkommere fødes med en Ulyst til det Gode og visse syndige Drifter til det Onde" (s. 31). Derimod synes der at foreligge en forskel i forholdet mellem disse og Balle. Mens Johan Grundtvig og Bastholm forklarer verdens ondskab ved hjælp af en velkendt bibelsk tradition, tager Balle sit udgangspunkt $\mathrm{i}$ almenmenneskelig erfaring. I lærebogens tredje kapitel, "Om Menneskets Fordærvelse ved Synden" hedder det $\mathrm{i}$ den indledende $\S 1$ :

Erfaring viser, at Mennesker ere ikke saa gode, som de burde være. Alle have de Feil, og hos dem alle yttrer sig enten en eller anden ond Tilbøielighed, skiønt i forskiellige Grader.

Denne indsigt uddybes i den følgende paragraf, hvor det hedder:

Den almindelige Fordærvelse hos Menneskene bestaaer fornemmeligen deri, at de ikke bruge deres Forstand til sund Eftertanke, og det, fordi en uordentlig Begierlighed efter de jordiske Ting, som behage Sandserne, er blevet (...) mægtig i deres Siæl. (§ 2)

Balles formulering: At ingen er så gode, som de burde være, er interessant bl.a., fordi man her har et bevinget ord, der anvendes af mange, men som kun få kender ophavsmanden til. I nærværende sammenhæng er det dog vigtigere at notere, at Balles henvisninger til erfaring, forstand og sund eftertanke markerer en bemærkelsesværdig forskel fra Johan Grundtvig, nemlig en overgang fra en bibelsk til en rationel begrundelse. Hos en tredje samtidig ved navn Andreas Krag Holm finder man en tilgang, der principielt er på linie med Balles, men hvis konkrete udformning dog rummer en interessant variation. I Krag Holms lærebog (1812) understreges det i tredje kapitel "Om Menneskets Fordærvelse ved Synden", at syndighed er et almenmenneskeligt fænomen:

$\S 2$. Da intet Menneske her i Livet vorder fuldkommen, Ingen naaer den høieste Grad af Viisdom, Frihed, Selvbeherskelse, er Ingen fri for Overtrædelse. Alle ere Syndere.(s. 96)

Overenssstemmelsen med Balle består deri, at også her tages udgangspunkt i almenmenneskelig erfaring. Imidlertid omformuleres Balles dictum: At ingen er så gode, som de burde være, til det lige så alment accepterede udsagn: At ingen er fuldkommen. - Henvisninger til menneskelig erfaring findes i øvrigt også i Bechmanns lærebog (s. 23,86 og 115).

\section{Larebøger for latinskolernes disciple}

Vi forlader hermed lærebøgerne for børn for at gå videre til det øverste trin i skolesystemet, gymnasieskolen også kaldet latinskolen eller den lærde skole. På dette område er antallet af lærebøger væsentligt mindre end for de såkaldte almueskolers vedkommende. Dette er en naturlig 
konsekvens af, at markedet for lærebøger til den højere skole, som den gang på landsbasis kun omfattede 15-20 skoler, selvsagt var mere begrænset end for det skoletilbud, der rettede sig mod hele befolkningen. I det følgende skal derfor kun fremdrages to lærebøger, der anvendtes i den højere skoles undervisning. Men først et par ord om de vigtigste bestemmelser vedrørende disse bøgers benyttelse.

I årene omkring år 1800 byggede latinskolens religionsundervisning på den Guldberg'ske forordning af 11. maj 1775. Ifølge denne forordning var grundlaget for religionsundervisningen de to store værker af Ove Høegh-Guldberg: Den naturlige Theologie (1765) og Den aabenbarede Theologie (1773). Disse bøgers enorme omfang $(227+529$ sider!) nødvendiggjorde, at man benyttede kompendier, i datiden betegnet "Udtog". På den baggrund autoriseredes i 1780 en mindre lærebog af B. G. Sporon: Den christelige Religions Hovedlaerdomme. Til Skolernes Brug i Danmark og Norge (1780). Få år senere udkom et andet "Udtog", der i vor sammenhæng er særlig interessant. Det vides, at Grundtvig ved optagelsen i Aarhus Katedralskole i 1798 anskaffede både Guldbergs Den aabenbarede Theologie og et kompendium ved Mathias Galthen: Catechetisk Udtog af S. T Geheimeraad Ove Høegh Guldbergs aabenbarede Theologie (1784, 2. oplag 1793). Få år senere benyttede den lidt yngre B. S. Ingemann akkurat den samme lærebog i Slagelse latinskole (Bugge 1999, 115 ff.). Vi skal nu se på, hvad disse lærebøger havde at sige om skabelse og syndefald.

\section{Om skabelse}

Første kapitel af Sporons lærebog fra 1780 indledes med en argumentation for åbenbaringens nødvendighed. I den forbindelse fastslås, at

Den naturlige Theologie, eller den sunde Fornuft, lærer os, at der er en Gud til, og at denne Gud bør æres og dyrkes af os. Men da den tillige lærer os, at vi synde idelig, det er at sige, ikke holde Guds Bud eller giøre hans Bud (...) saa kan det ikke andet end at være os om at giøre at vide, hvorledes denne hellige og retfærdige Gud kan tilfredsstilles, og vi behage ham ( $\AA$ benbaring er derfor nødvendig) ( 1 1).

Bemærkelsesværdig er her, at der sættes lighedstegn mellem "den naturlige Theologie" og "den sunde Fornuft". Endvidere noteres, at allerede i denne indledende sammenhæng henvises til "den sunde Fornuft" ikke alene med hensyn til Gudserkendelsen, men tillige med henblik på at fastslå den almindeligt udbredte syndighed som en uafviselig realitet. Specielt om skabelsen hedder det i $\S 12$ "Om Gud og hans Egenskaber":

Naturens Lys lærer os, at der er et saadant Væsen til. Thi vi begribe, at Verden ikke kan have skabt sig selv; ei heller kan den med saa 
sammenhængende en Orden og saa viise Indretninger være bleven (til) af en Hændelse, ligesaa lidet som enhver anden konstig Maskine. ${ }^{4}$

Af disse paragraffer ses, at den naturlige teologi her i overensstemmelse med den tilgrundliggende Høegh-Guldbergske dogmatik kaldes "den sunde Fornuft" og "Naturens Lys". Denne teologi går her et skridt videre end de tidligere citerede lærebøger for børn. Ikke blot lærer den, at der må være en Gud til; den begrunder tillige, hvorfor det er vigtigt at lære om ham og om vort forhold til ham. Også med hensyn til skabelsen går Sporon et skridt videre end Balle. Ligesom denne fastslår Sporon, at verden ikke kan have skabt sig selv. Men i stedet for at henvise til det hus, der ikke kunne bygge sig selv (det anses rimeligvis for lært allerede på et tidligere trin!), henvises her til verdens "sammenhængende Orden" og "viise Indretninger". ${ }^{5}$ Vi befinder os tydeligt nok på et højere abstraktionsniveau. Så vidt Sporon. Vi går nu videre til Mathias Galthens lærebog.

Galthen fastslår ligesom Sporon, at "Fornuften lærer os", at verden ikke kan være blevet til "ved en Hændelse" (§ 4). Og allerede i bogens allerførste kapitel henvises til, at om Gud lærer fornuften os, "at han (dvs. Gud) er til, har skabt og opholder Verden" (I. Kap. § 1). Galthen er altså på dette punkt forholdsvis kortfattet, formentlig fordi han har anset skabelsens kendsgerning for selvindlysende. Så meget desto udførligere udbreder han sig, som vi skal se, om syndefaldet.

\section{Om syndefald}

Som allerede konstateret, har Sporon indarbejdet sine fornuftbegrundede tanker om syndefaldet $\mathrm{i}$ de indledende paragraffer om åbenbaringens nødvendighed. Senere i bogen ( $(51)$ forankres tankerne om den almindelige syndighed i den bibelske tradition om syndefaldet, hvis eftervirkninger er en åbenlys, let iagttagelig, aktuel kendsgerning:

Af de faldne Mennesker (dvs. Adam og Eva) kunde ikke fødes Skabninger med større Fuldkommenheder, end de selv havde. Den efterfølgende menneskelige Slægt maatte da blive underkastet al den Uorden i Siæls og Legems Kræfter, som var Følgen af Guds Billedes Tab (s. 33). [Arvesynden kan derfor siges at bestå i] en af vore faldne Forfædre medfødt Uduelighed til det Gode og Tilbøielighed til det Onde (s. 34).

En appel til det fornuftige ræsonnement finder man her i konstruktionen: kunde ikke...maatte da. En lignende sammenkobling af begrundelser ud fra fornuften og erfaringen på den ene side og den bibelske tradition på den anden møder man i Galthens lærebog. I lærebogens kap 6 "Om Synden" hedder det, at "Erfarenhed lærer, og Skriften stadfæster, at alle Mennesker ere ufuldkomne, uduelige og syndige" (s. 31). Den meget høje vurdering af den ved fornuftens brug 
opnåede indsigt fremgår endvidere af kapitel 7 "Om Guds forbarmende Naade". At fornuften godtgør nådens nødvendighed, udvikles her $\mathrm{i}$ en treleddet argumentation, ifølge hvilken fornuften viser os, at vi for det første er "høisttrængende til Guds Forbarmelse", fordi den (dvs. fornuften) begriber "den Umuelighed for os, som Fordærvede, ved egne Kræfter at komme tilbage til vor første Fuldkommenhed" (s. 42). Dernæst pointeres, at "Fornuften finder det værdigt for Gud at ynkes over os", og endeligt redegøres der for, at "Fornuften lader os haabe, at Gud har forbarmet sig over os" (s. 4243).

Syndefaldets realitet eller for nu at bruge Balles ord, at ikke alle mennesker er så gode, som de burde være, understreges også i Galthens lærebog i hans kap. 13 "Om Loven og Evangelium”. Her hedder det, at "Naturens Lov", som er "Guds Villie om vort Forhold mod Gud, os selv og andre Mennesker", kunne kendes af alle ud fra fornuften og andres undervisning. Men, spørger Galthen,

Kiende alle Mennesker Naturens Lov? Alle Mennesker kunde kiende den; efterdi de alle ere begavede med en fornuftig Siel; men da en naturlig Dorskhed og Sandselighed giør de fleeste Mennesker efterladne til at bruge Fornuften, især i aandelige Ting; saa kiende de allerfleeste lidet eller intet til Naturens Lov. (s. 99).

I Galthens udførlige betragtninger over synden og dens konsekvenser, der let kan iagttages i menneskers daglige erfaring, bemærkes især to karakteristiske træk:

- Den problemløse sammenføjning af fornuft og helligskrift: "Erfarenhed lærer, og Skriften stadfæster". Der er ingen konflikt. Tværtimod består der et harmonisk forhold og en klar overensstemmelse mellem, hvad henholdsvis erfaringen og den hellige skrift lærer os.

- Prioriteringen. Erfaring, fornuft og kendskab til "Naturens Lov" indeholder de overordnede, afgørende forudsætninger for at forstå og tilegne sig det bibelske budskab om synd og nåde. Det er ud fra fornuften, at den enkelte kan forstå menneskets medfødte syndighed og dets deraf følgende uduelighed, ufuldkommenhed, dorskhed, sanselighed og behov for Guds nåde. Det er fornuften, og ikke for eksempel evangeliet, der kan indgive mennesker et håb om, "at Gud har forbarmet sig over os". 6

Sporons og Galthens gennemførte fremhævelse af erfaring og sund fornuft kan forklares på flere måder. Bøgerne er produkter af deres tid; de er blevet til i oplysningstiden, om end i denne periodes sidste fase. Endvidere er lærebøgerne selvsagt præget af de gældende bestemmelsers krav. Endelig må ikke overses, at bøgerne er beregnet til brug $\mathrm{i}$ datidenc ovmnacieskole altsล̊ nå skolesvstemets overste trin $\mathrm{Af}$ 
pædagogiske grunde har man fundet det hensigtsmæssigt at stimulere disse unges intellektuelle evner. Netop latinskolens begavede unge disciple, nationens håb, skulle nødigt gå hen og blive "efterladne til at bruge Fornuften, især i aandelige Ting".

\section{Anskuelsens appel}

Tiden er nu inde til at drage nogle konklusioner. Gennemgangen af eksempler fra tidens lærebøger $\mathrm{i}$ religion giver nogle konkrete holdepunkter for at forstå den appel, Grundtvig har lagt i sin sondring mellem tro og anskuelse. Det, han har kunnet forudsætte hos sine læsere og har kunnet appellere til, er to grundlæggende normalteologiske forudsætninger - for nu atter at anvende et tidligere formuleret udtryk. Disse normalteologiske forudsætninger, som Grundtvig delte med sin samtid, består af to selvindlysende, indiskutable antagelser med axiomatisk gyldighed:

- at verden er skabt af Gud og derfor oprindeligt var god, men

- at verden på et vist tidspunkt gik af lave. Ved et fald er den afveget fra sin oprindelige bestemmelse og er blevet uharmonisk og ond.

Disse antagelser gælder verden som sådan; de gælder derfor også mennesket. Og netop disse normalteologiske forudsætninger kunne Grundtvig i årene omkring 1830 trygt regne med var til stede hos læserne. Hvilke læsere, kunne man spørge. Principielt alle - i praksis færre, men i hvert fald nogle af dem, der havde modtaget en elementær kristendomsundervisning enten i skolen hos degnen eller under konfirmationsforberedelsen hos præsten. Grundtvig kan imidlertid næppe have forestillet sig, at hans 635 sider tykke bog skulle være hyggelæsning rundt omkring i de tusind hjem. Den læserkreds, han har haft for øje, må være det snævrere, men til gengæld toneangivende akademiske miljø. I datidens danske akademikeres normalteologiske forudsætninger indgik ikke alene barndomstidens tilegnelse af Balles lærebog, men tillige latinskolens religionsundervisning på grundlag af Høegh-Guldbergs dogmatik samt Sporons og Galthens "Udtog". Med rette har Martin Schwarz Lausten $(1983,196)$ fremhævet disse lærebøgers langtrækkende eftervirkning: "Det teologiske grundsyn, som disse fremstillinger byggede på, kom (..) til at præge alle akademikere i den følgende menneskealder".

\section{Nogle perspektiver}

Vi kan nu vende tilbage til Grundtvigs sondring mellem tro og anskuelse. Indledningsvis blev det fastslået, at i begrebet "Anskuelse" spiller syndefald en lige så væsentlig rolle som skabelse. Af den derpå 
følgende gennemgang af samtidens lærebøger i religion fremgik, at Grundtvig med rette kunne forvente, at en helt selvfølgelig accept af skabelsestanken og af syndefaldets realitet som selvindlysende sandheder indgik i hans læseres - altså også "Naturalisternes" normalteologiske forudsætninger. At sådanne forudsætninger ikke længere er til stede halvandet århundrede senere, er en væsentlig forskel mellem Grundtvigs tid og vor.

Fremdeles fremgår, at vi her finder forklaringen på "Anskuelsens" strukturelle ejendommelighed: Grundtvig forudsætter en enighed på to væsentlige områder - ikke ét område og ikke tre, men to. Også derfor kan lærebøgernes tale om skabelsen og det onde siges at udgøre - for nu at bruge et af Christian Thodbergs velvalgte udtryk fra en anden sammenhæng - "en glemt dimension" i fortolkningen af Grundtvigs tanker om "Anskuelsen".

Endelig kan spørgsmålet rejses, om de fremdragne forudsætninger også er teologiske? Er der ikke snarere tale om en slags filosofi? Ud fra en senere tids tankegang, ifølge hvilken udgangspunktet for kristen teologi er inkarnationens kendsgerning og Jesu evangelium, da må de forudsætninger, der her betegnes som normalteologiske, snarere klassificeres som før-teologiske antagelser af almenfilosofisk art. Således tænkte imidlertid hverken Grundtvig eller hans samtidige. For dem var disse antagelser teologi. De var udtryk for det, Høegh-Guldberg betegnede som "naturlig teologi" i modsætning til "åbenbaret teologi". Disse betegnelser finder man også i titlerne på de to dele af Ove Høegh-Guldbergs dogmatiske hovedværk, som der nu gentagne gange er refereret til. Den naturlige teologi bygger på fornuften og menneskenes hverdagserfaringer. Den åbenbarede teologi bygger på den hellige skrift og på den tro, der vækkes og vokser i mødet med Bibelens budskab. Forholdet mellem disse to slags teologi beskrives af Høegh-Guldberg med de ofte citerede ord om "den yndige Overensstemmelse mellem Fornuft og Skrift". Og, tilføjer han, "Er der noget angenemmere end at betragte det deilige Baand, som Fornuftens og Skriftens Lærdomme have med hinanden?"

I vore dage virker en sådan tankegang naiv og formuleringen nærmest komisk. Ikke således for Grundtvig og hans samtidige $\mathrm{i}$ begyndelsen af det 19. århundrede. Midt i sin allermest bibelkristne periode, i sin Verdenskrønike fra 1812, skrev Grundtvig om HøeghGuldbergs naturlige teologi følgende:

At giøre Danmark kristelig og dansk, det var hans (dvs. HøeghGuldbergs) herlige Øiemed (...) Tusinder skal velsigne hans Navn, thi Meget udrettedes. Istedenfor de latinske spidsfindige Sætninger, som gemte de lærde Skolers Kristendom, skrev han selv en naturlig Theologi, der ved Klarhed, Dybsindighed og hjertelig Varme maatte begeistre den ufordærvede Ungdom, og visselig lede til den aabenbarede (VK 1812, US II, 368-369). 
Her vedkender Grundtvig sig åbent sin gæld til Høegh-Guldberg og til latinskolens lærebøger i religion. Det er vel at mærke ikke HøeghGuldbergs rationalisme og moralisme, han vedkender sig, men den principielle sondring mellem en åbenbaringsteologi og en naturlig teologi, der "visselig (måtte) lede til den aabenbarede". Det noteres, at der ikke er tale om, at Grundtvig ukritisk overtager Høegh-Guldbergs teologi, men han indarbejder dele deraf i sin egen helhedsopfattelse. Det samme sker en halv snes år senere i nogle apologetiske udkast fra begyndelsen af $1820^{\prime}$ erne. Også her anvender Grundtvig en del af Høegh-Guldbergs tanker, hvor de indgår i "en aldeles forskellig Opfattelse af Kristendommen" (Høirup 1949, 194-198). Dette svarer til, at Grundtvig roser N. E. Balle for hans fastholden ved fædrenes tro, men vender sig kritisk imod Balles rationalisme på etikkens område. Her er han efter Grundtvigs opfattelse "veget for (...) Tidens Aand".

Sammenfattende kan konstateres, at de normalteologiske forudsætninger, som Grundtvig appellerede til med sin skelnen mellem tro og anskuelse, i ikke ringe grad er blevet til på grundlag af datidens religionslærebøger. Hermed er indføjet endnu en detalje i billedet af Grundtvigs arv fra oplysningstiden. Imidlertid gælder det $\mathrm{i}$ hans som $\mathrm{i}$ andre tilfælde, at det afgørende ikke er at modtage en arv, men at forvalte og videreføre denne.

\section{Forkortelser}

NM: N. F. S. Grundtvig (1832), Nordens Mythologi eller SindbilledSprog historisk-poetisk udviklet og oplyst, København.

PS I-IX: Svend Grundtvig (udg.) (1880-1930), N. F. S. Grundtvigs Poetiske Skrifter, bind 1-9, København.

US I-X: Holger Begtrup (udg.) (1904-09), Nik. Fred. Sev. Grundtvigs Udvalgte Skrifter, bind 1-10, København.

VK 1812: N. F. S. Grundtvig (1812), Kort Begreb af Verdens Krønike $i$ Sammenhoeng, København.

\section{Litteraturliste}

\section{Værker af Grundtvig}

Grundtvig, N. F. S. (1812), "Kort Begreb af Verdens Krønike i Sammenhæng" i US II, 165-422.

Grundtvig, N. F. S. (1832), "Nordens Mythologi eller SindbilledSprog - historisk-poetisk udviklet og oplyst af N. F. S. Grundtvig" i $U S \mathrm{~V}, 376-767$.

Grundtvig, N. F. S. (1871), "Kirke-Speil eller Udsigt over den christne Menigheds Levnetsløb" i US X, 165-422.

Grundtvig, N. F. S., tale ved biskop N. E. Balles begravelse d. 25. oktober 1816, her citeret efter gengivelsen i Dansk Kirketidende 
1885, sp. 80-362.

Grundtvig Svend (udg.) (1880-1889), N. F. S. Grundtvigs Poetiske Skrifter, bind 1-9, København (PS).

\section{Værker af andre forfattere}

\section{Larebøger, børneskolen}

Balle, N. E. (1791), Larebog i den Evangelisk-christelige Religion, 10. oplag, København 1833.

Bastholm, Chr. (1785), Religions-Bog for Ungdommen tilligemed Betragtninger over saadan en Bogs nyttigste Indretning, 4. oplag, København 1810.

Bechmann, H. G. (1813), Overhøring efter Laerebogen udi Hvirring og Hornborg Kirke, 5. oplag, København 1815.

Boisen, P. O. (1818), Udvikling af de i Larebogen forekommende Begreber, 2. oplag, København 1821.

Grundtvig, Johan (1779), Catechismi Forklaring efter Saliggiørelsens Orden, Godiche, København.

Holm, A. K. (1812), Undervisning i Religionen for Ungdommen, med Hensyn til den anordnede Larebog $i$ den evangelisk-kristelige Religion, København.

\section{Larebøger, latinskolen}

Galthen, Matthias (1784), Catechetisk Udtog af S. T. Hr. Geheimeraad

Ove Høegh Guldbergs aabenbarede Theologie, 2. oplag, København 1792.

Høegh-Guldberg, Ove (1765), Den naturlige Theologie: Tillige som en Indledning til den aabenbarede, København.

Høegh-Guldberg, Ove (1773), Den aabenbarede Theologie eller den hellige Skrlftes Hoved-Lardomme, København.

Sporon, B. G. (1780), Den christelige Religions Hovedlcerdomme. Til

Skolernes Brug i Danmark og Norge, 2. oplag, København. 1782.

\section{Anført litteratur}

Auken, Sune (2005), Sagas spejl. Mytologi, historie og kristendom hos N. F. S. Grundtvig, Gylling.

Barth, Karl (1947), Die protestantische Theologie im 19. Jahrhundert Ihre Vorgeschichte und ihre Geschichte, 2. oplag, Zürich 1952

Bugge, K. E. (1990), "Visdommens lænker" i Kirkehistoriske Samlinger, Selskabet for Danmarks Kirkehistorie, København. (1999), "Et Glimt fra Paradisets Kyst. Iagttagelser vedrørende Ingemanns skoletid 1800-1806" i Spor i sne, Danmarks Lærerhøjskole, København.

Haue, Harry (red.) (1991), Skole, dannelse, samfund: festskrlft til Vagn 
Skovgaard-Petersen, Odense Universitetsforlag, Odense.

Holm, Søren (1959), Oplysningstiden.Tanker og Livssyn, København. Høirup, Henning (1949), Grundtvigs Syn paa Tro og Erkendelse: Modsigelsens Grundsatning som teologisk Aksiom hos Grundtvig, København.

Kornerup, Bjørn et al. (red.) (1951), “Oplysningstiden 1746-1799” i Den danske Kirkes Historie, bd. V, København.

Larsen, Joakim (1914), Skolelovene af 1814 og deres Tilblivelse aktmoessig fremstillet, København.

Lausten, Martin Schwarz (1983), Danmarks kirkehistorie, 1. oplag, København.

Michelsen, William (1954,) Tilblivelsen af Grundtvigs historiesyn: Idehistoriske studier over Grundtvigs verdenskrøniker og deres littercere forudscetninger, København.

Philipp, Wolfgang (1957), "Das Werden der Aufklärung in theologiegeschichtlicher Sicht" i serien Forschungen zur systematischen Theologie und Religionsphilosophie, bd. 3, Göttingen.

Thodberg, Christian (1989), "En glemt dimension i Grundtvigs salmer" (1969), optrykt i Syn og sang. Poesi og teologi hos Grundtvig, København.

Thyssen, Anders Pontoppidan (1965), "Menneske først - Om Kaj Thanings Grundtvig-disputats" i Kirkehistoriske Samlinger, København.

Noter

NM 1832, US V, 400-403. - Tankegangen er udførligt refereret og kommenteret af Anders Pontoppidan Thyssen i Kirkehistoriske Samlinger (1965), 559-561 + 582-587 + 597-598.

2 Citatet fra kommissionsbetænkningen (1786) findes i Joakim Larsens tekstsamling (1914), 10. - Om den religionspædagogiske nyorientering se især Bugge 1990, 147-151. Det er Balles lærebog, 1814-lovene henviser til med udtrykket "Lærebogen", NB i bestemt form, jf. Larsen 1914, 426. Balles lærebog udkom i hele 10 oplag i perioden 1791-1833 samt i Reykjavik så sent som i 1854.

3 Vedr. Johan Grundtvigs katekismeforklaring og Grundtvigs kommentar dertil, se Bibl. nr.3 og Michelsen 1954, 188 f. - Benyttelsen af Balles lærebog ved konfirmandforberedelsen i Thyregod fremgår af Kirke-Speil, US X, 335. I Grundtvigs Verdenskrønike 1812 (VK 1812) er hans vurdering af lærebogen både positiv og negativ:

Balle skrev en Lærebog, som indeholder de kristelige Troessandheder uforfalskede, og det er store Ting, men Balle vilde afbøde Modstandernes Anfald, ved stedse at tale til Forstanden gennem kolde Begreber og give en Pligtlære i Tidens Smag (US II, 380).

I mindedigtet ved Balles død i 1816 finder man en kortfattet, negativ 
vurdering i slutningen af digtet: "Større var din Hæder blevet, / Lysere du havde levet, / Lagt dig gladere til Ro, / Hvis i intet, som i meget, / Tidens Aand du havde veget" (PS IV, 353). I mindetalen over Balle (Bibl.nr. 296) anvendes tilsvarende udtryk, men ingen direkte referencer til lærebogen. Stillet over for disse forbehold er det vigtigt at understrege Grundtvigs høje og livslange værdsættelse af Balles dåbsritual, jf. Thodberg 1969.

Som det fremgår, kunne man i oplysningstiden bruge udtrykket "Naturens Lys", lumen naturæ, både om den såk. naturlige teologi og om fornuften - især det sidste, se Holm 1959, 248-254, 284.

Til de "viise Indretninger", der bekræftede Skaberens visdom og omsorg, regnedes i datiden også den hensigtsmæssighed, man opdagede i planters, dyrs og menneskers fysiske egenskaber. I det 20. århundrede raillerede Karl Barth over denne såkaldte physicotheologi. Han var dog ikke uden forståelse for de pågældendes apologetiske anliggende, se Die protestantische Theologie im 19. Jahrhundert (1952), 138. Hertil har Wolfgang Philipp føjet den iagttagelse, at for tilhængerne af den naturlige teologi var det begrebet "Guds herlighed" (hebr.: Kabod, græsk: Doxa), der stod i centrum, ganske ligesom for ortodoksien, jf. Das Werden der Aufklärung (1957).

6 Om fornuften som “Overret”, se Holm 1959, 250.

7 Kornerup 1951, 270; Schwarz Lausten 1983, 195. - En overbevisning om overensstemmelse mellem helligskrift og sund fornuft foreligger allerede i den gammeltestamentlige og apokryfe visdomslitteratur (Ordsprogene og Siraks Bog), der spillede en væsentlig rolle i oplysningstidens morallære, jf. Bugge 1990, 154-160.

8 Citat fra mindedigtet ved Balles død, se ovf. note 3. Opgør med dem, der gav efter over for tidens krav på det etiske område, genfindes i den oprindelige form af Grundtvigs Roskilde Riim (1812), hvor oplysningstidens intentioner hånes med ordene: "Korte Salmer, korte Taler, / Eftergivende Moraler, / Unge skulde da med gamle / Flokkevis sig her forsamle" (PS III, 51). 